\title{
BENEDEK MARCELL MINT ABSZOLÚt PEDAGÓGUS?
}

\section{WAS MARCELL BENEDEK AN ABSOLUTE EDUCATOR?}

\author{
Hudra Árpád \\ szabadfoglalkozású filozófus, újságíró \\ hudir@t-online.hu
}

\section{ÖSSZEFOGLALÁS}

Benedek Marcell (1885-1969) tanár, író, irodalomtörténész, műfordító, színházigazgató életének vezérmotívuma, egész életre szóló célja volt „az olvasás művészetére” való tanítás. Így tehát joggal merült fel az a kérdés, hogy a katedra mögött álló vagy azt éppen nélkülöző Benedek Marcell a huszadik századi magyar értelmiség azon sajátos csoportjához sorolható-e, amelynek tagjait a Kiss Árpád Mühely egy évtizedes működése során és kutatásai alapján abszolút pedagógusoknak nevezett el. A tanulmány Benedek Marcell életrajzán keresztül tárja fel életének és munkásságának paradoxonait, és egyes műveinek témánk szempontjából legfontosabb kérdéseit megvizsgálva vonja le végső következtetését a címben feltett kérdésre.

\section{ABSTRACT}

Teaching the 'art of reading' was a leading motif, a life purpose for Marcell Benedek (1885-1969), teacher, writer, literary historian, literary translator, theatre director. Therefore, it is fair to ask whether standing behind the teacher's desk or having no desk at all, he could be considered being a member of that unique group of $20^{\text {th }}$ century Hungarian intellectuals who have been named 'absolute educators' by the Kiss Árpád Workshop based on a decade's worth of research during its ten years of operation. This study explores the paradoxes of Marcell Benedek's life and work through his biography. By analysing the most important issues raised in his writings relevant to our topic, the author arrives at the final conclusion to the question posed in the study's title.

Kulcsszavak: abszolút pedagógus, az olvasás művészete, transzfer, pedagógiai érosz, világszerűség, innováció, pedagógia és média

Keywords: absolute educator, the art of reading, transfer, pedagogic eros, worldliness, innovation, pedagogy and media 
„Az »olvasás müvészete« életének vezérmotívuma. Voltaképpen minden irodalomtörténeti és esztétikai munkáját ennek szentelte: közel hozni az olvasót a mühöz, a müt az olvasóhoz" - írta Benedek Marcellről a róla szóló életrajzi monográfiájában fia, Benedek István $(1977,158$.$) . Mindezek alapján nem tünik$ irrelevánsnak a kérdés: abszolút pedagógus volt-e Benedek Marcell abban az értelemben, ahogy ez a fogalom a Kiss Árpád Mühely mintegy évtizedes munkája során körvonalazódott? Nem válaszként, hanem a kérdésfeltevés alapjaként idézzük magát Benedek Marcellt: „Szeretett mesterem, Riedl Figyes mondotta egyik egyetemi előadásán: »az irodalomtanárnak az a hivatása, hogy megtanítsa a növendékeit - olvasni. [...] Ez döntő hatással volt rám. Hivatásnak, egész életre szóló célnak érzem, hogy olvasni tanítsak mindenkit, aki olvasni akar és szükségét érzi valami irányításnak." Pár sorral korábban pedig szinte felsőfokon jellemzi hivatástudatának kialakulását: „Egy emberöltővel ezelőtt, 1922-ben jelent meg először Bevezetés az olvasás művészetébe címü könyvem. Szerettem ezt a munkámat - elcsapott tanár létemre azzal a büszke érzéssel, amelyet később József Attila fogalmazott meg.

Én egész népemet fogom

nem középiskolás fokon

taní-

tani!"

(Benedek M., 1970, 5.)

Mindezek alapján annyit már most megjegyezhetünk, hogy Benedek Marcellnek az emberalakítás vágya valóban léte középpontját jelentette. Hiszen Faragó Lászlónak az abszolút pedagógusról szóló meghatározása - „Olyan géniusz, akinek az emberalakítás vágya jelentette léte középpontját" - irányítja vizsgálódásunkat. Géniuszról egyelőre szó sincs, a következőkben azt járjuk körbe az életrajzi kronológiát követve, hogy hogyan is állunk a pedagógia médiumában kibontakozó többoldalú kiemelkedő tehetség kérdésével Benedek Marcellnél, illetve azzal az alapkérdéssel, hogy senkiből sem lesz véletlenségből vagy kényszerüségből abszolút pedagógus. Ez mindig koncepcionális és akarati kérdés függvénye. Ebben az értelemben egzisztenciális döntés, hogy valaki abszolút pedagógus lesz-e, vagy sem. Tehát ennek a döntésnek a meglétét kell feltennünk kérdésként Benedek Marcellel kapcsolatban is.

Benedek Marcell némi túlzással nem is az életbe, hanem az irodalmi életbe született bele, mint Benedek Elek fia, aki Jókai Mór után az ország legolvasottabb írója volt. Családi elvárás: Marcellnek nagy íróvá kell válnia. Fia, Benedek István is megfogalmazta az ezzel kapcsolatos problémát, „hogy [apja] mindvégig otthonosabban mozgott az irodalomban, mint az életben, aminek csalódásai lecsillapították ugyan ifjonti hevességét, de élményei pótolhatatlanul elmaradtak. Ezért lett - legalábbis önmaga így ítéli meg - költő, drámaíró és regényíró helyett 
irodalmár és esztéta" (Benedek I., 1977, 5-6.). Egy biztos, gimnazista korában verses regényt írt (Don Juan feltámadása), valamint Rostand-darabot is fordított, amit elő is adtak a Nemzeti Színházban. A zenében is mutatott némi tehetséget, majd egyetemistaként társaival (Lukács György, Hevesi Sándor, Bánóczi László stb.) létrehozzák a modern és világirodalmi Thália Társulatot.

De ne szaladjunk ennyire elöre. Benedek Marcell szerint életpályáját három ember határozta meg példaképként, irányítóként: a mesemondó nagy székely, Benedek Elek, egyetemi tanára, az irodalomtörténész Riedl Frigyes és Romain Rolland, a nagy humanista francia író. Benedek Elek, aki Testamentum címmel (hat levéllel kiegészítve) élet- és erkölcsi útmutatót írt a fia számára, jelszószerüen három dolgot hangsúlyozott: a függetlenséget, azt, hogy harcolni kell minden igaz dologért, valamint a szeretetet. Itt idéznünk kell Benedek István véleményünk szerint lényegi megállapítását: „Egyetlen, amit nem tudott Benedek Elek: okosan bedobni fiát a mély vízbe, hogy tanuljon egyedül úszni” (Benedek I., 1977, 7.). Maga Benedek Marcell is apjára emlékező 1955-ös írásában azt írja, hogy „Kétségtelen, hogy az én világnézeti fejlődésemet bizonyos ponton nem engedte és máig sem engedi túljutni az ő hatása" (Benedek M., 1963, 251.). A szellemi örökség szempontjából fontos, hogy habár Benedek Elek nem a tanári pályát választotta (még az egyetemet sem fejezte be), számos, a néptanítóknak szóló és/vagy az ő érdekeiket szolgáló lapnál dolgozott. Ki kell emelni a gyermeklapokat, Jó Pajtás, illetve a már elcsatolt Erdélyben a Cimbora címü lapot, amelynek Elek nagyapó üzeni címủ rovatában gyermekekkel, de még a szüleikkel is levelezett. Benedek Marcell szerint apja a lányregények terén is forradalmat csinált, azaz újat, realitást hozott ebbe a müfajba. Úgy gondoljuk, hogy Benedek Marcell székely identitásának körbejárása céljából érdemes itt idéznünk a Tanácsköztársaság alatti, 1919-es rövid egyetemi tanári pályája egyetlen kiemelkedő tanítványának, Gyergyai Albertnek 1955-ös köszöntőjéből: „...s amely családi érzelmek és hagyományok titokzatos szövedékét fonta köréje, azt a »Benedek-misztériumot«, amely ezt az érzékeny és tartózkodó jellemet mintha ma is valami láthatatlan vértezettel védelmezné a nyers valóság, a profán világ ellen" (Gyergyai, 1968, 320-321.).

Benedek Marcell 1903 és 1907 között jár magyar és német szakosként a budapesti egyetemre, ahol olyan neves tanárok tanítottak, mint Alexander Bernát, Becker Fülöp, Beöthy Zsolt, Heinrich Gusztáv, Petz Gedeon, Riedl Frigyes, Szinnyei József. Az életrajzíró Benedek István szerint azonban csak egy ember volt igazán hatással Benedek Marcellra, ő viszont egész életére kihatóan: Riedl Frigyes. Az abszolút pedagógusság kérdése miatt foglalkoznunk kell Riedllel, ha már ilyen nagy hatással volt Benedek Marcellra tudósként és müvészlélekként, valamint tanárként egyaránt. Ezért érdemes Benedek Marcell Riedl Frigyesről szóló visszaemlékezéséhez fordulnunk. „Riedl igen egyszerünek látszó célt tűzött ki a tanár elé: tanítsa meg az embereket olvasni. De aki olvasásra 
akar tanítani, magának is meg kell tanulni ezt a művészetet. A müvészetben van egy adag beleérző képesség, a rokonság kutatása és felismerése író és olvasó között - de alapja mégiscsak a tudás. Mit kell tudnunk az íróról, hogy beleérző képességünk téves utakra ne kerüljön? (Benedek M., 1963, 307.) „Ránézve a kérdések ebben a sorrendben helyezkedtek el: milyen lelki adottságok hozták létre azokat az alkotásokat, amelyeken mi gondos kutatásokkal megállapítjuk a taine-i determinánsok hatását." (Uo.) Benedek Marcell azonban világosan látja, hogy ez a beállítottság azzal, hogy az írói egyéniséget fontosságban a mü mellé, sőt elé helyezi, komoly problémákhoz vezet Riedl Arany János könyvében is. Megjegyzi, hogy Riedl Arany Jánosából nemcsak a szeretetet olvashatjuk ki, hanem a be nem vallott, mélységes lelki rokonságot is. „Riedl fordított sorrendje, ahogy már említettem, az egyéni természetből indul ki. Az egyén - elméletileg is - ugyanannyira érdekli, mint a mü. Ezt az embert boncolgatja az Arany János. Az elemző szándék szabja meg a könyv szerkezetét, amely - valljuk meg - nem szerencsés. [...] Például nem kapunk összefüggő képet Arany lírájáról...” (Benedek M., 1963, 311.) Benedek Marcellt egyébként egyetemista korában nagyon vonzotta Riedl Frigyes tanári habitusa és oktatási módszere, aki szerinte partnerként kezelte már huszonöt évig tartó reálgimnáziumi tanítása során is diákjait, bevonva őket a fölvetett kérdések megoldásába. Egyetemi óráin is töprengve tanított, sohasem dogmatikusan, szemben a hallgatók néha heveskedő végítéleteivel. A Kiss Árpád Mủhely Benedek Marcellről szóló egyik beszélgetésén valaki megállapította, hogy Riedl Frigyesnek nem volt igazán „szellemi arcéle”. Voltaképpen ezt támasztja alá Németh G. Béla Az irodalomtörténeti pozitivizmus magyar mintamüve: Riedl Frigyes Arany-monográfiája címü tanulmányában (Németh G. B., 1975), amikor arról ír, hogy Riedl két ideál képét festette meg Aranyban, az erkölcsit mint a magyar faj eszményi megtestesítőjét, és a lélektanit, a lét eredendő nyomorúságát legmélyebben átérző emberét. Ez a két ideál pedig nem fér meg egymás mellett, sem gondolatilag, sem esztétikailag, s ezt az ellentétet nem is tudta feloldani, illetve „müvészileg”, müfaja müvészetével próbálta ezt megtenni. Kiváló lélektani alapú poétikai megfigyeléseivel nem tudta megoldani az egységes értelmezés funkcionális rendszerének kérdését. „Márpedig Riedl könyvének ez a döntő hiánya; hiányzik belőle a müvekbe foglalt tudatrétegek jelenségeinek az esztétikai létezésforma alapján történő szembesítése és megfeleltetése. Lélektan és poétika, poétika és esztétika, esztétika és filozófia, filozófia és etika, etika és történetfilozófia, történetfilozófia és szociológia; ezeken és a hozzájuk hasonló szembesítéseken és láncolatokon nem vitte keresztül sem a műveket, sem a fogalomkincset, melyekkel a müveket meg kívánta ragadni." (Németh G. B., 1976, 48.) Annyit azonban Németh G. Béla is elismer, hogy tanítványai jegyzetei alapján Riedl a hivatalostól eltérö, szabad és bátor, hierarchiaellenes és demokrata gondolkodásra is tudott serkenteni. Riedl tehát tudásoknak és magatartásoknak sok elemével rendelkezett, $\mathrm{s}$ volt egy bizo- 
nyos fajta karizmája is. Úgy tűnik azonban, hogy nem rendelkezett az abszolút pedagógusnak azzal a képességével, hogy az mindig egy egész világot közvetít a tanuló számára, amely a tudásoknak és magatartásoknak más és más elemekből összetevődő konkrét együttese. Életrajzi kronológia szerinti haladást ígértünk, ami egyben az abszolút pedagógussággal kapcsolatos kérdések keresztmetszetét is kell hogy jelentse. Benedek István szerint apja még az egyetemet sem fejezte volna be, csakhogy minél előbb az írói pályára léphessen. Kisegítő tanárkodások után, a fővárosi elhelyezkedés és a jövedelem miatt, valószínűleg Apponyi Albert volt vallás- és közoktatásügyi miniszter (1906-1910) segítségével, 1912-ben a Markó utcai fógimnáziumba került, és ott is tanított 1918-ig. Sajnos igen kevés dokumentum maradt fenn akkori tanárkodásáról, kiválóbb diákjai Benedek István szerint nagyon élvezték az előadásait, közülük többen is barátai lettek, így például: Juhász Vilmos, Sárközi György (a későbbi jeles író) és Szabolcsi Bence (az abszolút pedagógusok közé sorolható zenetudós, zenetörténész). Utóbbival élete végéig igen jó viszonyban volt. A sokoldalú Szabolcsi, akit Benedek a legnagyobb és a legszebben író zenetudósnak nevezett naplójában, s akinek - mint írta - annyi zenei gyönyörüséget és okulást köszönhet, nem tudjuk, hogy mit tanult az utóbbitól, csak feltételezéseink lehetnek. Benedek a naplójában megemlíti azt is, hogy három tanítványa: Hász, Szabolcsi és Sárközi tulajdonképpen konzervatív volt az ő radikális korszakában, és - mint fogalmaz - „nézeteim ellenére szerettek engem". Az mindenesetre felvethető, egyelőre még függetlenül attól, hogy Benedeket abszolút pedagógusnak minősítjük-e, hogy az utóbbinak esetleg jellemzője lehet az egykori tanítványok pályakövetése is. Röviden szólnunk kell gimnáziumi évei alatti egyre inkább radikalizálódó közéleti tevékenységéről, amely végül is a tanári pályától való megválásba torkollt. Benedek Marcell fokozatosan eltávolodott a nemzeti és keresztény oldaltól, kapcsolatba került a Galilei Körrel és Jászi Oszkárral, de párthoz sohasem csatlakozott. Ezenkívül belépett a Tanáregyesületbe, „ahol a baloldali szervezkedés lelkes propagálója” [a titkára volt $-\mathrm{H}$. Á.] és egy szabadkőmúves páholyba (a klerikalizmus ellen), „itt a destruktívnak nevezett konstruktív elégedetlenkedők vezetője” (Benedek I., 1977, 74.). 1918. június 22-én a IV. Országos Középiskolai Tanárkongresszus előadója, ahol meghirdeti: „Kultúra proletárjai egyesüljetek!” (Benedek I., 1977, 87.) Monográfusa szerint ekkor alakította ki nagyon határozott polgári humanista-demokrata világnézetét, $\mathrm{s}$ ehhez minden politikai változás közepette hü maradt. Annak ellenére, hogy nem volt kommunista, a Tanácsköztársaság alatt egyetemi tanárságot vállal francia irodalomból. Annak bukása után gimnáziumában fegyelmi bizottság elé állították, de Benedek Marcell elhatározta, hogy még a vád elhangzása előtt önként lemond állásáról, „mert ha engedik, sem akar a »fajmagyar« irányzatban tanítani” (Benedek I., 1977, 99.). Ezt a lépést bátor, hősies értelmiségi magatartásnak neveznénk a részünkröl, különösen három gyermekkel a háta mögött. 
Ekkortól mintegy huszonöt évig lényegében csak müfordításaiból él, és független embernek érzi magát a tanári pályán maradtakkal szemben. Nem hallgatnánk el monográfusának véleményét sem, aki szerint ,a középiskolai tanári tevékenység is csak kényszerítő kitérő volt az életpályán, lényénél fogva nem termett erre a hivatásra. Talán a közéleti tevékenységet is az okozta, hogy nem találta helyét a középiskolában. Az eredmény az volt, hogy elszakadt a tudománytól is, az irodalomtól is: hat év alatt egy közepes regényen kívül nem »termelt« semmit" (Benedek I., 1977, 96.). Az említett Vulkán (1918) című regényről Füst Milán írt annak hibáit alaposan feltáró kritikát, azzal zárva azt, hogy a jövőben jobb regények is kikerülhetnek írójának kezei közül. Véleményünk szerint paradox helyzet, hogy éppen a tanári munkától való megválás és az önálló alkotói pályára való lépés kísérlete után válik Benedek Marcell munkásságának meghatározó jellemzőjévé, minden területen és müfajban, egyféle nevelői szenvedély, amit talán nevezhetnénk pedagógiai érosznak is. A „transzfer” tehát megvalósul, jelentős alkotói képességek irányulnak a tanítás és a nevelés irányába. Gyergyai Albert, Marcel Proust nagy fordítója így jellemzi Benedek Marcellt: „Fordítani sokféle okból lehet - nemcsak kenyérkeresetként, unalomból vagy mükedvelésből, hanem tudatos nevelö céllal, mesterségbeli öntudattal, s a közlésnek, az ismeretterjesztésnek azzal az önzetlen vágyával, amely örömét, élményeit nem tudja magában tartani, s másokkal is szeretné megosztani - s Benedek Marcell legtöbb fordítását ez a szép kívánság inspirálja." (Gyergyai, 1968, 327.)

Most érdemes tisztáznunk, hogy mit is jelent az olvasás müvészete Benedek Marcellnél? Metafora vagy használható, a megértést szolgáló fogalom? Egyszerre magyarázni és tanítani is kell? Amennyiben az utóbbi kettő is, azt akkor hogyan lehet megtenni? Ki az, aki ezt csinálja? Benedek véleménye szerint az olvasó nemcsak passzív, hanem aktív befogadója is a münek, ami nélkül az nem is fejtheti ki hatását, voltaképpen ekkor készül el. Hangsúlyozza, hogy „Az olvasás igenis müvészet, végső soron közel járna az írás müvészetéhez...” „Az olvasás müvésze az, akiben a megformálás adományán kívül minden megvan, ami az írót íróvá teszi” (Benedek M., 1970, 9.). Itt szerintünk két kérdés is akad. Akiben megvan ez a tehetség, azt minek tanítani, másrészt, akiben nincs meg, abban fel lehet-e ezt ébreszteni? Az elsőre a válasz az, hogy nincs olyan tehetség, amit okos szóval, ismeretekkel fejleszteni ne lehetne. A másodikra a válasz pedig, hogy „Ami ebben az aktivitásban az egyén vele született sajátosságának következménye (pl. fantázia, érzékiség) - azon változtatni nem lehet. Ami azonban az életkörülményekkel, szociális helyzettel, korral, az ízlés és a tudás, az általános műveltség, az erkölcsi felfogás minőségével függ össze: az fejleszthető. És mert azok az adományok, amelyek az irodalom élvezéséhez szükségesek, éppenséggel nem ritkák: ezért nem lehetetlen feladat az irodalmi élvezet tudatossá tétele, az olvasás múvészetévé való kifejlesztése az olvasóközönség tízezreiben.” (Benedek M., 1970, 11.) Ugyancsak fogas kérdés az az állítás, hogy a müélvezés kulcsa: az 
olvasó önmagát találja meg a müben. Hiszen az olvasó egy fércmüben is magára ismerhet. Benedek válasza erre az irodalom és a nem irodalom különbségének magyarázata. Van azonban ehhez kapcsolódóan még egy nehéz kérdés: hogyan élvezhetjük azokat a remekmüveket, amelyekbe nem tudjuk önmagunkat beleképzelni-beleérezni? Itt „a tetszés elengedhetetlen feltétele, hogy bele tudjuk élni magunkat abba az atmoszférába, amit a művész teremt. És ebben segít a magunk nevelése." (Benedek I., 1977, 162.)

Azonban Benedek Marcellnél nemcsak az olvasás müvészet, hanem az irodalomtörténet-írás is. Már A modern magyar irodalom (1924) elején így ír Benedek István szerint: „Az irodalomtörténet írásához csupa művészi tulajdonság szükséges: megértö- és átélőképesség, ízlés és formaérzék, egyéni világnézet, s végül stilizáló képesség - hiszen az irodalomtörténet maga is müvészi alkotás. Kell hozzá tudás is, de az »ezer apróbb-nagyobb adat ismerete, módszeres felkutatása« csak olyan előfeltétele az irodalomtörténetírás müvészetének, mint a festékkeverés »tudománya« a festészetnek [...] Aki csak ennyit tud, ne lépjen az olvasók elé." (Benedek I., 1977, 229.)

Benedek Marcell irodalomesztétikájában (Benedek M., 1936) magát a kritikust is müvésznek nevezi, ,akinek bírálata egy megíratlan és tudatosan soha rendszerbe nem szedett filozófiába illeszkedik bele". Ebben a munkájában nyilvánvalóvá válik, hogy irodalomszemlélete a Benedetto Croce-i intuíció módosított fogalmán alapul. Így Benedek Marcell szerint „Minden müvészet a beleérző képzelet megnyilatkozása.” „Az intuíció teszi a müvészetet - s így az irodalmat is - a megismerés legfőbb eszközévé; a szabály teszi érzékelhetővé, közölhetővé a megismerést. A megismerés - láttuk - hatalom; a hatalom: élvezet. Az író gyönyörködtet bennünket. Van-e a gyönyörködésnek erkölcsi jelentősége?" (Benedek M., 1936, 13.) „Mủvészet és erkölcs - egy. Vagyis: az erkölcs maga nem mủvészet, de a müvészetet nem lehet elválasztani az erkölcstöl.” (Benedek M., 1936, 14.) „Ha az író művészete nem játék, még kevésbé az a kritikus művészete. Erkölcsi és társadalmi felelőssége még nagyobb. A müvész beleérző képességén és formaérzékén kívül tárgyi tudásra, intellektuális áttekintésre is szüksége van.” „Az esztétikus-kritikusnak tanító és nevelő szerepe a közönséggel szemben fontosabb mint az íróval szemben. [...] Az irodalomesztétika arra való, hogy tudatosabbá tegye, elmélyítse az olvasó kritikáját és az író önkritikáját." (Benedek M., 1936, 20.) „Végül pedig: az irodalomesztétika fegyver is - talán a legerősebb fegyver - az irodalom szabadságáért vívott harcban. [...] A maga tehetségén és erkölcsi gerincén kívül [az írónak - H. Á.] más támasza nincs, mint a közszellemet nevelö kritika, amely az írói szabadság politikai vagy üzleti ellenségeinek szünetlenül magyarázza, hogy mi az irodalom. Ha az egész közszellem szabadságellenessé válik: az esztétikának szembe kell szállnia az egész közszellemmel. [...] Irodalom és szabadság: egy - mondom befejezésül. Csak szabad irodalom fejezheti ki az ember belső és külső világát.” (Benedek M., 1936, 20.) 
Benedek Marcell talán legaktívabb pedagógusi időszaka az 1945-46-os kolozsvári egyetemi tanárság volt, amikor esztétikát és irodalmi kritikát tanított. Emellett dramaturgja volt a Magyar Színháznak és vezetője a Kamaraszínháznak. Itt írta (az asztalfióknak) a Madách Imre életét, munkásságát és $A z$ ember tragédiáját az 1883-as bemutatót követő kávéházi beszélgetés keretében feldolgozó igen kreatív rádióhangjátékát.

Benedek Marcell Lukács György meghívására 1947-62 között drámatörténetet tanított az Eötvös Loránd Tudományegyetemen, és müfordítási gyakorlatokat tartott.

Akkori tanítványa, Szekér Endre (1981) szerint a kisszámú hallgatóság előtt rendkívül szerényen, saját írásairól, kutatásairól nem beszélve, úgy adott elö, mintha ezrekhez szólna.

Összegezve: úgy tűnik, hogy Benedek Marcell életművének több olyan vonása is van, amelyek az abszolút pedagógusok kritériumai közé tartoznak. Nem kétséges, hogy többoldalú és bizonyos területeken kiemelkedő alkotói képességekkel rendelkezett. Kiemelkedő fordító volt, összesen több mint kétszáz művet fordított magyarra, elsősorban franciából, de németből és angolból is. Kiváló lexikográfusnak tekinthetö, az általa föszerkesztett 1963-65-ös Magyar Irodalmi lexikon úttörő jelentőségü. Regényíróként nem emelkedett a legjobbak közé, de több regénye alapján is közepes regényírónak tekinthető. Jól értett a dramaturgiához és a színházi rendezéshez is. Önmegvalósításként élte meg, hogy a mintegy szabadnak és függetlennek tekinthető, kitartó és termékeny irodalomtörténészi és esztétikai tevékenységét a tanítás és nevelés szolgálatába állítsa. Küldetéstudata mindenkire vonatkozóan és minden korszakban érvényesült. Koherens módon, az olvasást, az irodalomtörténetírást és a kritikát egyaránt művészetnek tekintette. Ez az irodalmi szemléletmód fogalmilag azonban nem hozott új eredményeket, irodalomszemlélete minden esetleges látszat ellenére tradicionális maradt. Ezen alapulhat, hogy még értékítéletei sem tekinthetőek valóban innovatívnak. Az olvasás múvészetének fogalma pedig mintegy csábít az abszolút pedagógia megvalósítása irányába. Gondoljuk csak meg, hogy ehhez a „művészethez” hányféle fogalmat és tudásterületet kellett számításba vennie, „egymásba játszania”, azonban ez diszciplinárisan mégsem járt új eredményekkel nála. Amennyiben viszont adott fogalmak állandó határátlépését, a világszerüség, az univerzalitás irányába való kitágítását az abszolút pedagógia alapvető jellemzőjének tartjuk, akkor Benedek Marcellt nem tekinthetjük abszolút pedagógusnak.

(A tanulmány figyelembe vette a szerzőnek a Kiss Árpád Műhely keretében 2017-ben Benedek Marcellről tartott előadását követő vita eredményeit is.) 


\section{IRODALOM}

Benedek I. (1977): Benedek Marcell. Budapest: Magvető Könyvkiadó

Benedek M. (1928): Hamlet tanár úr. Budapest: Dante (év nélkül)

Benedek M. (1936): Ember, világ és irodalom. Budapest: Franklin-Társulat

Benedek M. (1961): Romain Rolland. Budapest: Gondolat Kiadó

Benedek M. (1963): Könyv és színház. Budapest: Szépirodalmi Könyvkiadó

Benedek M. (1965): Naplómat olvasom. Budapest: Szépirodalmi Könyvkiadó

Benedek M. (1968): Szépen élni. Budapest: Magvető Könyvkiadó

Benedek M. (1970): Az olvasás müvészete. Budapest: Gondolat Könyvkiadó

Benedek M. (1990): Délsziget, avagy a magyar irodalom története. Budapest: Kelenföld Kiadó

Gyergyai A. (1968): A Nyugat árnyékában. Budapest: Szépirodalmi Könyvkiadó

Németh G. B. (1976): Létharc és nemzetiség. Budapest: Magvetö Könyvkiadó

Spranger, E (1946): A pedagógiai géniusz. EROS. (ford. Faragó L.) Budapest: Egyetemi Nyomda

Szekér E. (1981): Érték és írás. Kecskemét: Forrás Egyesület

Szekér E. (1994): Benedek Marcell. Budapest: Balassi Kiadó 